\title{
Merske značilnosti slovenske oblike Vprašalnika usmerjenosti k sreči (OTH)
}

\author{
Andreja Avsec ${ }^{* 1}$ in Tina Kavčič² \\ ${ }^{1}$ Oddelek za psihologijo, Filozofska fakulteta, Univerza v Ljubljani \\ ${ }^{2}$ Pedagoška fakulteta, Univerza na Primorskem
}

\begin{abstract}
Povzetek: V članku sva preverjali merske značilnosti Vprašalnika usmerjenosti k sreči OTH (Peterson, Park in Seligman, 2005), ki meri tri različne načine doseganja sreče, to je preko užitka (hedonizem), smisla (eudaimonia) in vpletenosti (zanos). Vprašalnik je bil v več korakih preveden v slovenščino (dva neodvisna strokovna prevoda, usklajevanje, prevod nazaj $\mathrm{v}$ angleščino, usklajevanje). 1064 udeležencev, starih od 18 do 91 let, je poleg usmerjenosti k sreči poročalo še o zadovoljstvu s svojim življenjem. Konfirmatorna faktorska analiza je pokazala mejno sprejemljivo prileganje naših podatkov predpostavljenemu trifaktorskemu modelu. Rezultati so pokazali tudi zadovoljivo notranjo skladnost vseh treh lestvic (alfa koeficienti od 0,70 do 0,83 ) ter ustrezno visoko povezanost med posameznimi postavkami in skupnimi rezutlati na pripadajočih lestvicah. Dobljeni koeficienti interkorelacije so pokazali nizko povezanost med usmerjenostjo k užitku in usmerjenostjo k smislu ter zmerno povezanost usmerjenosti k vpletenosti z obema ostalima usmerjenostima. Moški in ženske se med seboj niso statistično pomembno razlikovali v samoocenah usmerjenosti k sreči, starost udeležencev pa je bila statistično pomembno, vendar nizko povezana z nižjo usmerjenostjo k užitku. Ob upoštevanju demografskih značilnostih udeležencev sta usmerjenosti k užitku in k vpletenosti pomembno izboljšali napoved zadovoljstva z življenjem. Rezultati tudi kažejo, da so s svojim življenjem najbolj zadovoljni tisti posamezniki, ki so se razmeroma visoko ocenili na vseh treh lestvicah usmerjenosti k sreči.
\end{abstract}

Ključne besede: Vprašalnik usmerjenosti k sreči, zadovoljstvo z življenjem, užitek, vpletenost, smisel

\section{Psychometric properties of the Slovene version of the Orientations to Happiness Questionnaire}

\author{
Andreja Avsec ${ }^{1}$ in Tina Kavčič ${ }^{2}$ \\ ${ }^{1}$ Department of Psychology, Faculty of Arts, University of Ljubljana, Slovenia \\ ${ }^{2}$ Faculty of Education, University of Primorska, Slovenia
}

\begin{abstract}
The Orientations to Happiness Questionnaire (OTH; Peterson, Park in Seligman, 2005) measures three routes to happiness: life of pleasure (hedonism), life of meaning (eudemonia) and life of engagement (flow). The questionnaire was adapted to Slovene in several steps (two independent translations by experts, reaching agreement, retranslation; modification) and its psychometric properties were examined with 1064 participants, aged 18 to 91 years. The participants also rated their satisfaction with life. Confirmatory factor analysis indicated adequate fit of the expected three-factor model. Results showed satisfactory internal consistency of the three scales (alpha coefficients ranged from 0.70 to 0.83 ) and satisfactory itemtotal correlations. Inter-correlation coefficients suggested low associations between orientation to pleasure and orientation to meaning, while orientation to engagement was moderately related to the other two orientations to happiness. Men and women did not differ statistically significantly in their self-reported orientations to happiness, while age of the participants had a significant, though small negative effect on orientation to pleasure. After accounting for demographic characteristics orientations to pleasure and engagement significantly improved the prediction of subjective life satisfaction. Results also indicate that satisfaction with life was highest in participants relatively high on all three orientations to happiness.
\end{abstract}

Key words: Orientations to Happiness Questionnaire, life satisfaction, pleasure, engagement, meaning

\footnotetext{
${ }^{*}$ Naslov/Address: dr. Andreja Avsec, Oddelek za psihologijo, Filozofska fakulteta, Univerza v Ljubljani, Aškerčeva 2, 1000 Ljubljana; e-pošta: andreja.avsec@psiha.net
}

Članek je licenciran pod pogoji Creative Commons Attribution 4.0 licence. / The article is licensed under a Creative Commons Attribution 4.0 International License. 
V zadnjih desetih letih je problematika psihičnega blagostanja in sreče pogosto osrednja tema psiholoških raziskav tako na aplikativnih kot na bazičnih področjih psihologije. $\mathrm{K}$ dvema temeljnima pristopoma oz. vidikoma raziskovanja psihičnega blagostanja - eudaimonskemu in hedonskemu - Vprašalnik usmerjenosti k sreči OTH (Peterson, Park in Seligman, 2005) dodaja še tretjega, in sicer posameznikovo aktivno vpletenost v dejavnost. Vprašalnik usmerjenosti k sreči OTH torej meri različne načine oz. poti doseganja sreče, to je preko smisla, užitka ali vpletenosti. Vprašalnik so raziskovalci že večkrat uporabili v raziskavah kot mero ali pa kot napovednik psihičnega blagostanja, vendar je šlo večinoma za raziskave na angleško govorečih področjih, precej manj pa je podatkov o veljavnosti te mere v drugih jezikovnih oz. kulturnih področjih. V tem prispevku želiva preveriti merske značilnosti slovenske različice vprašalnika in s tem prispevati $\mathrm{k}$ razumevanju medkulturnih razlik v pomenu posameznih načinov oz. poti do sreče.

\section{Tri poti do sreče}

Posamezniki težijo k povečanju svojega psihičnega blagostanja na različne načine. Nekateri iščejo izzive v različnih dejavnostih, drugi se trudijo, da bi naredili svet lepši, boljši in v njem poiskali smisel, mnogi pa iščejo srečo skozi različne senzorne izkušnje in druge užitke. Avtorji vprašalnika OTH (Peterson idr., 2005) so želeli natančneje opredeliti in operacionalizirati te težnje, pri čemer izhajajo iz dveh tradicionalnih pristopov k proučevanju sreče (Ryan in Deci, 2001) in jima dodajajo še tretjo možno pot k sreči.

Prvi raziskovalni pristop je hedonizem, stara filozofska tradicija, izhajajoča iz osnovne težnje posameznika, da maksimizira užitek in minimiza bolečino (Waterman, 1993). Kahneman (1999) opredeljuje hedonsko psihologijo kot novo področje psihologije, katere predmet proučevanja so stvari, ki naredijo izkušnje in življenje prijetno in neprijetno, ter enači konstrukta hedonizem in psihično blagostanje. Hedonski pristop k raziskovanju psihičnega blagostanja je prisoten tako v relativno ozki usmeritvi proučevanja čutnih zadovoljitev kot tudi v širši usmeritvi proučevanja posameznikovih želja in njegovih interesov, ki privedejo do sreče in pozitivnih čustev. Več raziskav (pregled v Seligman, Parks in Steen, 2005) je ugotovilo pozitivne posledice doživljanja pozitivnih čustev na zdravje, na ustvarjalno in učinkovito mišljenje in na višjo odpornost proti stresu.

Drugo vejo tradicije, eudaimonizem, podobno kot hedonizem lahko najdemo $\mathrm{v}$ antični filozofiji (Waterman, 1993). Eudaimonska tradicija poudarja, da je za posameznikovo psihično blagostanje potrebno več kot samo dobro počutje. Predvideva, da ni nujno, da izpolnitev želja in teženj vodi k višjemu psihičnemu blagostanju, tudi če pri njihovi izpolnitvi posameznik uživa. Zato s tega vidika subjektivne sreče ne bi smeli enačiti s psihičnim blagostanjem. Psihično blagostanje naj bi temeljilo na aktualizaciji človekovih potencialov, torej na uresničevanju posameznikove prave narave. Waterman (1993) meni, da se eudaimonija pojavi, ko so posameznikove dejavnosti skladne $\mathrm{z}$ njegovimi najbolj temeljnimi vrednotami in so v celoti vključene v njegovo delovanje. Medtem ko naj bi bila hedonija povezana s sproščenostjo, pa je eudaimonija bolj povezana $z$ izzivi in posameznikovim trudom. Podobno C. D. Ryff in Singer (2008) menita, da psihično blagostanje ne more vključevati zgolj uživanja, pač pa gre za težnjo k popolnosti, ki predstavlja uresničevanje posameznikovih pravih potencialov.

Vpletenost v dejavnost ali predanost dejavnosti sta avtorja vprašalnika izbrala kot tretjo možno usmeritev k sreči, ki izhaja iz teorije zanosa (Csikszentmihalyi, 1990). Zanos se nanaša na stanje, ki se pojavi ob optimalnem ravnovesju med sposobnostmi in izzivom. V stanju zanosa je posameznik popolnoma osredotočen na dejavnost, drugače zaznava čas (ponavadi mu mine zelo hitro), samozavedanje v smislu samokritike je zmanjšano. Posamezniku je stanje zanosa tako izpolnjujoče in prijetno, da je notranje motiviran za to dejavnost. Zanos tako lahko dolgoročno vodi $\mathrm{k}$ višjemu psihičnemu blagostanju, saj posameznik preko njega lahko razvija svoje interese in sposobnosti. Tako ni presenetljivo, da je Waterman (1993) enačil stanje zanosa $\mathrm{z}$ eudaimonijo (poimenoval jo je osebna ekspresivnost). Kasneje pa je na podlagi svojih podatkov zaključil, da zanos ne vključuje le eudaimonskih, ampak tudi hedonske značilnosti, saj dejavnosti, v katerih doživlja zanos, posameznik naknadno dojema kot samonagrajujoče oziroma skrajno prijetne. Kljub temu pa zanosa ne moremo enačiti z užitkom, saj $\mathrm{v}$ samem stanju zanosa ni prisotno doživljanje ugodja. Posameznik sicer ponavadi opisuje, da je stanje zanosa zanj izredno prijetno, vendar gre za naknadno oceno po stanju zanosa (Peterson, Ruch, Beermann, Park in Seligman, 2007). Podobno tudi avtorji vprašalnika OTH (Peterson idr., 2005) predvidevajo, da je zanos poseben konstrukt, zato so ga $\mathrm{v}$ svojem vprašalniku OTH opredelili kot posebno usmerjenost.

\section{Oblikovanje in struktura vprašalnika OTH}

Avtorji (Peterson idr., 2005) so se lotili oblikovanja vprašalnika tako, da so za vsako od treh usmerjenosti predlagali po 12 postavk. Na podlagi odgovorov 180 udeležencev so s pomočjo komponentne analize, ki je potrdila smiselnost treh faktorjev, izbrali po šest postavk na lestvico in oblikovali končno obliko vprašalnika OTH. V nadaljnji raziskavi, v kateri so preverjali merske značilnosti vprašalnika, je sodelovalo 845 oseb. Eksploratorna komponentna analiza je pokazala tri 
faktorje z lastnimi vrednostmi nad 1, pri čemer so bile vse postavke najbolj nasičene $\mathrm{z}$ ustreznim faktorjem. Najvišjo povezanost so ugotovili med lestvicama vpletenost in smisel $(r=0,46)$, najnižjo pa med užitkom in smislom $(r=0,18)$.

Schueller in Seligman (2010) sta nadalje preverila merske značilnosti vprašalnika pri vzorcu 13.565 oseb iz 112 držav, čeprav je treba poudariti, da so vsi udeleženci izpolnjevali angleško različica vprašalnika. Konfirmatora faktorska analiza je pokazala zadovoljivo, a ne idealno prileganje podatkov predpostavljenemu trifatorskemu modelu, zato sta avtorja zaključila, da bi bila morda primernejša drugačna faktorska struktura, vendar nista predlagala možnih alternativ.

P. Anić (2012) meni, da bi bil za vprašalnik OTH morda primeren hierarhični model z dvema ravnema. $\mathrm{V}$ tem modelu avtorica na prvi ravni predvideva tri usmerjenosti $\mathrm{k}$ sreči, na višjem pa hedonsko in eudaimonsko usmerjenost, pri čemer slednja vključuje usmerjenosti $\mathrm{k}$ smislu in $\mathrm{k}$ vpletenosti, vendar tega modela avtorica ni preverjala. Pri vzorcu 769 študentov iz Reke je z eksploratorno komponento analizo odkrila dve komponenti. Prva komponenta je vključevala postavke iz lestvic usmerjenosti $\mathrm{k}$ smiselnosti in usmerjenosti $\mathrm{k}$ vpletenosti, druga komponenta pa postavke iz lestvice užitek. Dve postavki je zaradi majhne nasičenosti na teh dveh komponentah izločila iz nadaljnje analize.

$\mathrm{Za}$ izločitev ene postavke so se odločili tudi raziskovalci, ki so preverjali merske značilnosti vprašalnika pri 578 tajvanskih študentih (Chen, Tsai in Chen, 2010). Konfirmatorna faktorska analiza je namreč pokazala ustrezno prileganje podatkov trifaktorskemu modelu samo v primeru, da so izločili to postavko. Pri kitajskem vzorcu 671 študentov (Chen, 2010) so z eksploratorno komponentno analizo prav tako dobili tri komponente, pri čemer se niso vse postavke uvrščale na predpostavljene komponente, nekaj postavk pa je imelo tudi visoka sekundarna nasičenja. S konfirmatorno faktorsko analizo je avtor $\mathrm{z}$ izločitvijo ene postavke in manjšimi prilagoditvami uspel podpreti trifaktorski model. Predpostavljeno trifaktorsko strukturo so podprli tudi pri španskih (San Martín, Perles in Canto, 2010) in japonskih študentih (Kumano, 2011).

Merske značilnosti vprašalnika OTH so bile poleg za izvirno angleško različico ter hrvaško, kitajsko, japonsko in špansko, ki smo jih že omenili, objavljene še za nemški prevod. Avtorji (Ruch, Harzer, Proyer, Park in Peterson, 2010) so preverjali merske značilnosti vprašalnika pri dveh vzorcih udeležencev. Prvi vzorec je sestavljalo 4.174 udeležencev, ki so vprašalnik izpolnili preko spleta, drugi vzorec pa 1.152 udeležencev, ki so vprašalnik izpolnili v papir-svinčnik obliki. Klasična konfirmatorna faktorska analiza ni podprla ustreznosti trifaktorskega modela za nobenega od vzorcev, zato so uporabili postopek eksploratorne komponentne analize, ki omogoča tudi preverjanje prileganja podatkov modelu. Preverjali so ustreznost eno-, dvo-, tri- in štirifaktorskega modela na obeh vzorcih. Najbolj ustrezen se je izkazal štirifaktorski model za oba vzorca, zaradi primerljivosti rezultatov analiz s predhodnimi pa so se odločili za izviren, trifaktorski model, ki se je prav tako izkazal za ustreznega. Avtorji poročajo tudi o zelo visoki skladnosti faktorskih nasičenj za obe različici vprašalnika (spletne in papir-svinčnik).

Iz dosedanjih raziskav lahko povzamemo, da se je vprašalnik izkazal za dokaj zanesljivo in veljavno mero treh usmerjenosti k sreči, pri čemer so rezultati analiz pri nekaterih vzorcih udeležencev pokazali sekundarne nasičenosti manjšega števila postavk ali celo uvrščanje posameznih postavk na neustrezno komponento. Drug problem je, da se predvsem lestvica vpletenosti precej prekriva $z$ lestvico smisla. Ali je vpletenost ločena pot do sreče in je ne moremo enačiti niti z usmerjenostjo $\mathrm{k}$ smislu niti $\mathrm{z}$ usmerjenostjo $\mathrm{k}$ užitku, je vprašanje teoretične narave, pri čemer različni avtorji ponujajo različne razlage (npr. Seligman, 2002; Vittersø, 2003; Vittersø in Søholt, 2011).

\section{Napovedna veljavnost usmerjenosti k sreči}

Za preverjanje napovedne veljavnosti vprašalnika OTH so raziskovalci večinoma izbrali konstrukt zadovoljstva z življenjem. Zadovoljstvo z življenjem predstavlja kognitivno komponento subjektivnega blagostanja in se nanaša na posameznikovo oceno njegovega življenja na podlagi subjektivnih, posamezniku lastnih kriterijev (Pavot in Diener, 1993). Zadovoljstvo z življenjem bi torej moralo biti pozitivno povezano $\mathrm{z}$ vsemi tremi usmerjenostmi k sreči, saj avtorji vprašalnika OTH predvidevajo, da je vsaka od treh usmerjenosti možna in ustrezna pot do sreče (Peterson idr., 2005). Avtorji so v svoji raziskavi podprli to pričakovanje, saj so bile vse tri usmerjenosti pomembno povezane $\mathrm{z}$ zadovoljstvom $\mathrm{z}$ življenjem, pri čemer sta bili usmerjenost $\mathrm{k}$ smislu in usmerjenost $\mathrm{k}$ vpletenosti močnejša napovednika kot usmerjenost k užitku (Peterson idr., 2005). Skupaj so vse tri usmerjenosti pojasnile dodatnih $12 \%$ variabilnosti v zadovoljstvu z življenjem ob upoštevanju demografskih značilnosti. Avtorji so predvidevali, da za doseganje zadovoljstva z življenjem niso pomembne samo posamezne usmerjenosti k sreči ampak tudi, ali posameznik uporablja več kot eno pot doseganja sreče. Rezultati so pokazali, da so se kot razmeroma najbolj zadovoljne ocenili posamezniki, ki so poročali o visoki izraženosti vseh treh usmerjenosti k sreči.

Kasnejejevečraziskav podprlonapovednoveljavnost vprašalnika OTH za zadovoljstvo z življenjem, ocenjenim z vprašalnikom SWLS (Diener, Emmons, Larsen in Griffin, 1985). Pri severnoameriškem spletnem vzorcu 18.326 oseb (Vella-Brodrick, Park 
in Peterson, 2008) so avtorji ugotovili pomembno napovedno veljavnost vseh treh usmerjenosti $\mathrm{k}$ sreči, tudi ob upoštevanju spola in starosti, pri čemer so vse tri usmerjenosti skupaj pojasnile dodatnih $20 \%$ variance zadovoljstva z življenjem. V medkulturni raziskavi z udeleženci iz 27 držav (Park, Peterson in Ruch, 2009) so ugotovili statistično pomembno povezanost vseh treh usmerjenosti $\mathrm{k}$ sreči z zadovoljstvom z življenjem, najnižja je bila povezanost zadovoljstva $\mathrm{z}$ življenjem $\mathrm{z}$ usmerjenostjo kužitku $(r=0,20)$, višja pazusmerjenostjo $\mathrm{k}$ vpletenosti $(r=0,36)$ in usmerjenosti k smislu $(r=$ $0,38)$. Ruch in sodelavci (2010) prav tako poročajo, da je bilo zadovoljstvo $z$ življenjem pomembno povezano $\mathrm{z}$ vsemi tremi usmerjenostmi ( $r=0,26 \mathrm{z}$ užitkom; $r=$ $0,29 \mathrm{z}$ vpletenostjo; $r=0,24 \mathrm{~s}$ smislom) tudi pri dveh nemško govorečih vzorcih. Vse tri usmerjenosti so bile tudi pomemben napovednik zadovoljstva z življenjem, skupaj so pojasnile $13 \%$ variabilnosti v zadovoljstvu z življenjem. V španski študiji (San Martín idr., 2010) so ugotovili precej nižjo povezanost med usmerjenostmi $\mathrm{k}$ sreči in zadovoljstvom z življenjem (najvišji $r=0,19$ za vpletenost). Vse tri usmerjenosti so skupaj z izobrazbo in spolom pojasnile zgolj $6 \%$ variance zadovoljstva $\mathrm{z}$ življenjem in $5 \%$ variance srečnosti, merjene z Lestvico srečnosti SHS (Lyubomirsky in Lepper, 1999). Kot pomemben napovednik zadovoljstva $\mathrm{z}$ življenjem se je izkazala samo lestvica vpletenosti, kot pomemben napovednik srečnosti pa lestvica užitka. V japonski raziskavi (Kumano, 2011) sta bili z zadovoljstvom z življenjem povezani le lestvici usmerjenost $\mathrm{k}$ smislu in usmerjenost $\mathrm{k}$ vpletenosti, kar avtorji razlagajo $\mathrm{z}$ medkulturnimi razlikami in različnim pojmovanjem koncepta sreče in zadovoljstva $\mathrm{v}$ zahodnih kulturah in na Japonskem. Po drugi strani raziskava s kitajskimi študenti ugotavlja pomembnost vseh treh usmerjenosti za zadovoljstvo z življenjem, pri čemer tudi to kulturo, tako kot japonsko, lahko uvrstimo med kolektivistične (Mayer, 2007).

\section{Demografske značilnosti in poti do sreče}

$\mathrm{V}$ nekaterih raziskavah omenjajo tudi povezave demografskih značilnostih $\mathrm{s}$ tremi usmerjenostmi. Peterson in sodelavci (2005) npr. ugotavljajo statistično pomembno, a nizko negativno povezanost usmerjenosti $\mathrm{k}$ užitku s starostjo in izobrazbo ter višjo izraženost usmerjenosti k užitku pri samskih kot pri poročenih, medtem ko se ostali dve usmerjenosti z demografski značilnostmi nista statistično pomembno povezovali. Podobno so tudi nemški raziskovalci (Ruch idr., 2010) ugotovilipomembnonegativno povezanostusmerjenosti $\mathrm{k}$ užitku s starostjo in zakonskim stanom, poleg tega pa je $v$ nemški študiji nekoliko naraščala usmerjenost $k$ vpletenosti z doseženo izobrazbo udeležencev. Druge statistično pomembne (a zelo nizke) povezave med posameznimi usmerjenostmi k sreči in demografskimi značilnostmi so se pokazale le pri enem od dveh vzorcev udeležencev v tej študiji.

\section{Namen raziskave}

Namen študije je bil preveriti psihometrične značilnosti slovenske priredbe vprašalnika OTH. Glede na rezultate analiz vprašalnika $v$ izvirni angleški obliki in več prevodih sva pričakovali, da bo hipotetična trifaktorska struktura podprta tudi $\mathrm{s}$ slovenskimi udeleženci. Napovedno veljavnost sva preverjali s konstruktom zadovoljstva z življenjem, pri čemer sva ga za razliko od dosedanjih raziskav merili z eno postavko in ne z Lestvico zadovoljstva z življenjem SWLS (Diener idr., 1985). Ena postavka kot mera zadovoljstva z življenjem se v raziskavah uporablja že več kot 30 let (npr. Andrews in Withey, 1976), pogosto tudi $\mathrm{v}$ medkulturnih raziskavah (Veenhoven, 2012). Ta postavka je vsebinsko ustrezna mera zadovoljstva $\mathrm{z}$ življenjem (Mellor, Stokes, Firth, Hayashi in Cummins, 2008), saj je po eni strani povsem osebna oz. subjektivna ter abstraktna (Cummins, Eckersley, Pallant, Van Vugt in Misajon, 2003), kar je bistvena značilnost konstrukta subjektivnega blagostanja, po drugi strani pa je tesno povezana tudi $\mathrm{z}$ emocionalno komponento subjektivnega blagostanja (Davern, Cummins in Stokes, 2007), podobno kot Lestvica zadovoljstva z življenjem SWLS. Pričakovali sva tudi, da bodo vse tri usmerjenosti $\mathrm{k}$ sreči pomembni napovedniki zadovoljstva z življenjem. Poleg tega sva predvidevali, da se bo izraženost posameznih načinov doseganja sreče povezovala $\mathrm{z}$ nekaterimi demografskimi značilnostmi udeležencev. Natančneje, pričakovali sva predvsem negativno povezanost usmerjenosti k užitku s starostjo, kar so že pokazale opisane predhodne raziskave in je tudi skladno s starostnimi spremembami v prioritetah vrednot (Musek, 2000).

\section{Metoda}

\section{Udeleženci}

V študiji je sodelovalo 1064 oseb (27,5 \% moških in $72,5 \%$ žensk), starih od 18 do 91 let $(M=38,9 ; S D$ $=16,1$ leta). $5 \%$ udeležencev je uspešno zaključilo osnovnošolsko izobraževanje, $50 \%$ udeležencev je uspešno zaključilo srednješolsko izobraževanje in 45 \% udeležencev je uspešno zaključilo vsaj višješolsko izobrazbraževanje. Približno $1 \%$ sodelujočih je bilo dijakov, $25 \%$ študentov, $53 \%$ zaposlenih, $5 \%$ brezposelnih in $13 \%$ upokojenih (2\% udeležencev je izbralo možnost drugo). Glede na stan, je bilo $25 \%$ sodelujočih samskih, $34 \%$ poročenih, $13 \%$ jih je živelo v izvenzakonski skupnosti, $23 \%$ pa jih je bilo v resni zvezi (6 \% udeležencev je izbralo možnost drugo). 


\section{Pripomočki}

Vprašalnik usmerjenosti k sreči OTH (Orientations to Happiness; Peterson idr., 2005) meri tri možne načine oz. poti k sreči, in sicer usmerjenost $\mathrm{k}$ užitku, usmerjenost $\mathrm{k}$ smislu in usmerjenost $\mathrm{k}$ vpletenosti. Vsaka od treh lestvic vsebuje po šest postavk. Primeri postavk vključujejo »Ko se odločam, kaj bom počel, vedno pomislim, ali bo to koristilo drugim ljudem.« za smisel, »Življenje je prekratko, da bi se odrekali užitkom, ki jih nudi.« za užitek in »Delu ali igri se ponavadi tako predam, da pozabim na vse drugo.« za vpletenost. Udeleženci na 5-stopenjski lestvici ocenjujejo, kako dejansko živijo svoje življenje (1 sploh ni značilno zame; 5 - zelo značilno zame). Višje število točk predstavlja višjo usmerjenost $\mathrm{k}$ doseganju sreče na določen način. Avtorji izvirnika (Peterson idr., 2005) navajajo alfa koeficiente notranje skladnosti 0,82 za smisel, 0,82 za užitek in 0,72 za vpletenost, ustrezno notranjo skladnost pa so podprli (alfa koeficienti preko 0,74) tudi pri vzorcu preko 13 tisoč udeležencev iz 112 držav (Schueller in Seligman, 2010). Vprašalnik sta avtorici pričujočega članka neodvisno prevedli iz originalne angleške različice v slovenščino, primerjali prevoda in ju združili, nato je dipl. anglistka prevedla vprašalnik nazaj $\mathrm{v}$ angleški jezik. Ta prevod smo nato primerjali $\mathrm{z}$ originalom in vsebinsko uskladili manjša neskladja med njima.

Subjektivno zadovoljstvo z življenjem. Sodelujoči so podali splošno oceno svojega trenutnega življenja na lestvici od 0 do 10 , kjer 0 pomeni »na splošno najslabše možno življenje«, 10 pa pomeni »na splošno najboljše možno življenje«. Postavka se pogosto uporablja tudi samostojno kot mera kognitivne komponente subjektivnega blagostanja, z različnimi ocenjevalnimi lestvicami (od 4 do 13 stopenjske). Andrews in Robinson (1991) poročata o povprečni korelaciji 0,68 med odgovori na isto postavko v razmiku 15-20 minut in o konvergentni veljavnosti postavke.

\section{Postopek}

Udeleženci so vprašalnika izpolnili na spletu. Povezavo na raziskavo so prejeli na svoj elektronski naslov. V študijo sva vključili študente nekaterih programov treh slovenskih javnih univerz, ki so nato pridobili za sodelovanje še druge udeležence različnih starosti. Da bi zagotovili čim manjšo pristranost vzorca, je bila povezava na raziskavo objavljena tudi na nekaterih zasebnih straneh, brskalnikih in v časopisu. Na uvodni strani spletne raziskave so bili udeleženci obveščeni o namenu raziskave in podali informirano soglasje za sodelovanje. Zagotovljena je bila zaupnost podatkov. Zbiranje podatkov je trajalo približno eno leto.

\section{Rezultati}

\section{Faktorska struktura vprašalnika OTH}

Za preverjanje prileganja podatkov pričakovani strukturi vprašalnika sva izvedli konfirmatorno faktorsko analizo (s programom AMOS 18). Skladno $\mathrm{z}$ opisom analiz $\mathrm{v}$ članku, ki opisuje konstrukcijo lestvic (Peterson idr., 2005), sva preverjali model s tremi predpostavljenimi latentnimi spremenljivkami s po 6 manifestnimi spremenljivkami, pri čemer sva dopuščali vzajemno povezanost med tremi latentnimi spremenljivkami. Dobljene nasičenosti posameznih postavk s pripadajočim faktorjem so prikazane v tabeli 1. Garson (2012) priporoča navajanje več pokazateljev prileganja podatkov predpostavljenemu modelu, in sicer $\chi^{2}$ vrednost, RMSEA in eno od mer prileganja podatkov modelu $\mathrm{v}$ primerjavi $\mathrm{z}$ ničelnim modelom. Ugotovljeni $\chi^{2}$ (CMIN) je znašal 1197,79 $(d f=132, \quad p=0,000)$. Statistično pomembna vrednost $\chi^{2}$ kaže na neustrezno prileganje modelu. Ker pa je ta vrednost močno pod vplivom velikosti vzorca, je bila statistična pomembnost te vrednosti pričakovana in ne odraža nujno slabega prileganja. NFI indeks, ki odraža odstotek izboljšanega prileganja podatkov merskemu modelu v primerjavi z ničelnim modelom (neodvisni model, ki predpostavlja neodvisnost med izmerjenimi in latentnimi spremenljivkami in s tem maksimalno vrednost $\chi^{2}$ ), naj bi presegal vrednost 0,90 oz. glede na bolj liberalne kriterije vsaj 0,80 . Za pričujoči model je NFI znašal 0,802, kar pomeni, da merski model izboljša prileganje podatkov za $80 \% \mathrm{v}$ primerjavi z ničelnim modelom ter bi $\mathrm{v}$ skladu $\mathrm{z}$ bolj liberalnimi kriteriji pomenil ustrezno prileganje modelu. Prednost RMSEA indeksa je, da ne zahteva primerjave merskega modela $\mathrm{z}$ ničelnim, ter da je razmeroma najmanj pod vplivom velikosti vzorca. Vrednost RMSEA pod ali enako 0,05 pomeni dobro prileganje, pod ali enako 0,08 pa ustrezno prileganje modelu. $\mathrm{V}$ preverjanem merskem modelu je RMSEA znašal 0,087 (meje $90 \%$ intervala zaupanja so znašale od 0,083 do 0,092 ), kar pomeni mejno sprejemljivo prileganje naših podatkov modelu.

$\mathrm{Na}$ podlagi rezultatov preliminarno izvedene eksploratorne analize glavnih komponent sva se odločili še za preverjanje modela brez postavk 4 in 9 , ki se nista jasno razvrščali na predpostavljeno lestvico (Vpletenost). Ostale specifike konfirmatornega modela so bile enake kot $\mathrm{v}$ analizi $\mathrm{z}$ vsemi postavkami. Dobljeni indeksi prileganja za ta model so znašali: $\chi^{2}$ $=731.81(d f=101, p=0,000)$, NFI $=0,857$ in RMSEA $=0,077$ (meje $90 \%$ intervala zaupanja od 0,071 do 0,082). Z izjemo zaradi velikega vzorca pričakovano statistično pomembnega $\chi^{2}$, dobljeni indeksi kažejo na zadovoljivo prileganje podatkov merskemu modelu. Zaradi ohranjanja primerljivosti rezultatov $\mathrm{z}$ rezultati 
Tabela 1. Rezultati konfirmatorne faktorske analize vprašalnik OTH $(N=1064)$

\begin{tabular}{llr}
\hline Postavke & & $\begin{array}{r}\text { Standardizirani } \\
\text { neposredni učinki }\end{array}$ \\
\hline Smisel & OTH2 & 0,69 \\
& OTH5 & 0,34 \\
& OTH11 & 0,68 \\
& OTH12 & 0,78 \\
& OTH14 & 0,66 \\
& OTH17 & 0,36 \\
Užitek & OTH3 & \\
& OTH8 & 0,73 \\
& OTH13 & 0,63 \\
& OTH15 & 0,62 \\
& OTH16 & 0,81 \\
& OTH18 & 0,68 \\
Vpletenost & OTH1 & 0,56 \\
& OTH4 & \\
& OTH6 & 0,43 \\
& OTH7 & 0,56 \\
& OTH9 & 0,61 \\
& OTH10 & 0,72 \\
& & 0,50 \\
\hline
\end{tabular}

predhodnih analiz sva se odločili obdržati prvotno obliko vprašalnika, torej sva $\mathrm{v}$ nadaljnjih analizah ohranili vse postavke ${ }^{1}$.

\section{Opisna statistika vprašalnika OTH}

V tabeli 2 predstavljava opisno statistiko za celotni vzorec. Poleg aritmetičnih sredin in standardnih deviacij so navedeni koeficienti asimetrije in sploščenosti, ki kažejo, da so se rezultati na vseh treh lestvicah porazdeljevali razmeroma normalno. Razpon rezultatov udeležencev je znašal od 6 do 30 za lestvici usmerjenosti $\mathrm{k}$ smislu in usmerjenosti $\mathrm{k}$ užitku ter od

${ }^{1}$ Zaradi manj kot optimalnega prileganja podatkov predpostavljenemu modelu, sva v skladu s predpostavkami P. Anić (2012) preverjali še dvofaktorsko strukturo vprašalnika OTH. Eksploratorna analiza glavnih komponent $\mathrm{Z}$ vnaprej določenim številom komponent (2) je pokazala, da se postavke, ki se nanašajo na usmerjenost $\mathrm{k}$ smislu in usmerjenosti $\mathrm{k}$ vpletenosti uvrščajo na isto komponento, na drugo pa postavke usmerjenosti $\mathrm{k}$ užitku, pri čemer so se za postavki 4 in 9 zopet pokazale dvojne nasičenosti. Rezultati konfirmatornih analiz so pokazali nezadovoljivo prileganje podatkov dvo-faktorskemu modelu, in sicer tako tistemu $\mathrm{z}$ vsemi postavkami $\left(\chi^{2}=1698,57(\mathrm{df}=134, \mathrm{p}\right.$ $=0,000) ; \mathrm{NFI}=0,719 ;$ RMSEA $=0,105 \mathrm{z}$ mejami $90 \%$ intervala zaupanja od 0,100 do 0,109$)$ kot tudi tistemu brez postavk 4 in 9 $\left(\chi^{2}=1207.60(d f=103, p=0,000) ; \mathrm{NFI}=0,764 ; \mathrm{RMSEA}=0,10\right.$ z mejami $90 \%$ intervala zaupanja od 0,095 do 0,106$)$. Zbrani podatki se torej bolje prilegajo modelu s predpostavljenimi tremi faktorji kot dvofaktorskemu modelu.
8 do 30 za usmerjenost $\mathrm{k}$ vpletenosti. Alfa koeficienti so bili vsaj 0,70 ali več, kar kaže na ustrezno notranjo skladnost lestvic. Korelacije med skupnimi rezultati na lestvici in pripadajočimi postavkami so znašali od 0,30 do 0,72 (glej vrstici označeni z $r_{c \min }$ in $r_{\text {cmaks }} \mathrm{v}$ Tabeli 2). Field (2009) kot kriterij ustrezne povezanosti med postavkami in skupnim rezultatom na lestvici navaja vrednost okrog 0,30. Dobljeni rezultati torej kažejo, da so se vse postavke vprašalnika ustrezno visoko povezovale $\mathrm{z}$ lestvicami OTH. Lestvice so bile statistično pomembno, nizko (med smislom in užitkom) do zmerno visoko povezane med seboj. Korelacije med OTH lestvicami in demografskimi spremenljivkami so bile nizke. Statistično pomembni korelacijski koeficienti so pokazali na negativno povezanost med starostjo in usmerjenostjo $\mathrm{k}$ užitku, na pozitivno povezanost dosežene izobrazbe $\mathrm{z}$ usmerjenostjo $\mathrm{k}$ smislu in usmerjenostjo $\mathrm{k}$ vpletenosti ter negativno $\mathrm{z}$ usmerjenostjo $\mathrm{k}$ užitku, na nekoliko višje rezultate na lestvici usmerjenosti k smislu pri ženskah kot pri moških ter nekoliko višje rezultate poročenih/v izvenzakonski skupnosti na lestvici usmerjenosti k vpletenosti in nižje na lestvici usmerjenosti k užitku v primerjavi z ostalimi udeleženci.

$\mathrm{V}$ nadaljevanju sva $\mathrm{z}$ analizo kovariance preverjali učinek spola in starosti udeležencev na njihove samoocene tega, v kolikšni meri srečo dosegajo preko smisla, užitka in vpletenosti. Moški in ženske, ki so sodelovali $\mathrm{v}$ študiji, se med seboj niso statistično pomembno razlikovali $\mathrm{v}$ povprečni starosti $(t(1062)=$ 1,$92 ; p>0,05 ; M_{\mathrm{m}}=40,4$ in $M_{\check{\check{z}}}=38,3$ leta), kar opravičuje

Tabela 2. Opisna statistika za lestvice OTH

\begin{tabular}{lccr}
\hline & Smisel & Užitek & Vpletenost \\
\hline Opisne statistike & & & \\
$M$ & 19,99 & 21,76 & 20,85 \\
$S D$ & 4,47 & 4,56 & 3,65 \\
Asimetričnost & $-0,25$ & $-0,57$ & $-0,17$ \\
Sploščenost & $-0,13$ & 0,22 & 0,01 \\
$\alpha$ & 0,75 & 0,83 & 0,70 \\
$r_{\text {cmin }}$ & 0,30 & 0,52 & 0,35 \\
$r_{\text {cmaks }}$ & 0,62 & 0,72 & 0,59 \\
Interkorelacije & & & \\
Užitek & $0,22^{* * *}$ & & \\
Vpletenost & $0,43^{* * *}$ & $0,42^{* * *}$ & \\
Korelacije z demografskimi spremenljivkami & \\
Starost & 0,05 & $-0,28^{* * *}$ & 0,00 \\
Spol & $0,09^{* *}$ & 0,00 & $-0,04$ \\
Izobrazba v letih & $0,11^{* * *}$ & $-0,15^{* * *}$ & $0,14^{* * *}$ \\
Stan & $-0,06$ & $0,19^{* * *}$ & $-0,07^{*}$ \\
\hline
\end{tabular}

Opombe. $N=1064 . r_{\text {cmin }}$ pomeni najnižji in $r_{\text {cmaks }}$ najvišji koeficient korelacije med postavko in skupnim rezultatom. Vrednosti za spol: $0=$ moški, $1=$ ženski; stan: $0=$ poročen ali v izvenzakonski skupnosti, $1=$ samski, v zvezi ali drugo.

${ }^{*} p<, 05 ;{ }^{* *} p<, 01 ;{ }^{* * *} p<, 001$. 
Tabela 3. Napoved subjektivnega zadovoljstva $z$ življenjem

\begin{tabular}{lccc}
\hline & $\beta$ & $\Delta R^{2}$ & $F$ \\
\hline Demografske & & & $F(4,1032)$ \\
spremenljivke & & 0,020 & $=5,27^{* * *}$ \\
$\quad$ Spol & $-0,02$ & & \\
$\quad$ Starost & $-0,08^{*}$ & & \\
$\quad$ Izobrazba & $0,08^{*}$ & & \\
Stan & $-0,06$ & & $F(3,1029)$ \\
& & & $=31,98^{* * *}$ \\
Usmeritve k sreči & & 0,084 & \\
$\quad$ Smisel & 0,05 & & \\
$\quad$ Užitek & $0,18^{* * *}$ & & $=16,99^{* * *}$ \\
$\quad$ Vpletenost & $0,15^{* * *}$ & & \\
\hline & & & $F(7,1029)$ \\
Skupaj & & 0,099 & $=10$.
\end{tabular}

Opombe. $N=1064$. Vrednosti za spol: $0=$ moški, $1=$ ženski; stan: $0=$ poročen ali $\mathrm{v}$ izvenzakonski skupnosti, $1=$ samski, $\mathrm{v}$ zvezi ali drugo.

${ }^{*} p<, 05 ;{ }^{* * *} p<, 001$.

vnos podatka o starosti kot kovariatne spremenljivke v analizo kovariance (Field, 2011). Rezultati predhodnega Levenovega testa so pokazali, da se variance rezultatov na vseh treh lestvicah med skupinami ne razlikujejo statistično pomembno. Rezultati so pokazali, da se spola ne razlikujeta statistično pomembno v nobeni od treh usmeritev k sreči (glej tudi Tabelo 3), prav tako ni bil statistično pomemben učinek interakcije med spolom in starostjo za nobeno od treh lestvic. Starost udeležencev ni imela statistično pomembnega učinka na rezultate pri lestvicah usmerjenosti $\mathrm{k}$ smislu in $\mathrm{k}$ vpletenosti, pokazal pa se je statistično pomemben učinek starosti na usmerjenost k užitku $(F(1,1060)=63,07 ; M S E=$ 1212,$84 ; p=0,000 ;$ parcialna $\left.\eta^{2}=0,056\right)$. S starostjo udeležencev se je zniževala izraženost usmerjenosti $\mathrm{k}$ užitku. Podrobnejša opisna statistika za OTH lestvice glede na spol in starost udeležencev je predstavljena $\mathrm{V}$ Tabeli A v Prilogi).

\section{Napovedna veljavnost vprašalnika OTH}

Udeleženci so ocenili tudi, v kolikšni meri so zadovoljni s svojim življenjem. Ta ocena zadovoljstva z Življenjem se je nizko, a statistično pomembno (vsi $p$ $=0,000)$ povezovala $\mathrm{z}$ njihovimi rezultati na lestvicah usmerjenosti k smislu $(r=0,16)$, užitku $(r=0,24)$ in vpletenosti $(r=0,26)$. V nadaljevanju sva s postopkom hierarhične regresijske analize napovedovali zadovoljstvo udeležencev $\mathrm{z}$ njihovim življenjem $\mathrm{z}$ dvema sklopoma napovednikov. V prvem koraku sva $\mathrm{v}$ regresijsko analizo vnesli spol $(0=$ moški, $1=$ ženski $)$, starost, izobrazbo $\mathrm{v}$ letih in $\operatorname{stan}(0=$ poročen ali $\mathrm{v}$ izvenzakonski skupnosti; 1 = samski, v zvezi ali drugo) udeležencev, v drugem koraku pa njihove rezultate na treh lestvicah OTH. Rezultati hierarhične regresijske analize so predstavljeni v Tabeli 3. Vsi vključeni napovedniki so skupaj pojasnili $10,4 \%$ variance $\mathrm{v}$ ocenah zadovoljstva z življenjem. Ocene zadovoljstva so nekoliko upadale s starostjo in naraščale $\mathrm{z}$ doseženo izobrazbo udeležencev ${ }^{2}$. Ob upoštevanju demografskih podatkov, je k zadovoljstvu je pomembno prispevalo doseganje sreče preko užitka in preko vpletenosti.

Da bi preverili, ali je sočasna višja izraženost vseh treh usmeritev povezana $z$ višjim blagostanjem, sva udeležence razvrstili v tri kategorije: v prvo so se uvrstili udeleženci, ki so na vseh treh lestvicah OTH dosegli rezultat pod mediano $(N=232)$, v tretjo tisti, ki so na vseh treh lestvicah imeli rezultate nad mediano $(N=176)$, v drugo pa vsi ostali $(N=629)$. Rezultati analize variance so pokazali, da so se oblikovane skupine udeležencev med seboj statistično pomembno razlikovale $\mathrm{v}$ subjektivnem zadovoljstvu z življenjem $\left(F(2,1034)=23,46 ; p=0,000\right.$; parcialna $\left.\eta^{2}=0,043\right)$, statistično pomembne so bile tudi razlike med vsemi pari skupin, ocenjene s Scheffejevim post hoc testom. Najbolj so bili zadovoljni s svojim življenjem posamezniki, ki so se visoko (nad mediano) ocenili na vseh treh lestvicah usmerjenosti k sreči $(M=7,61 ; S D=$ 1,50), nekoliko manj posamezniki z visoko izraženemi nekaterimi OTH lestvicami in nizko izraženimi preostalimi $(M=6,98 ; S D=1,75)$ ter najmanj zadovoljni tisti, ki so se na vseh treh lestvicah ocenili nizko $(M=$ $6,41 ; S D=1,94)$.

\section{Razprava}

Prispevek predstavlja merske značilnosti slovenske priredbe Vprašalnika usmerjenosti k sreči OTH (Peterson idr., 2005). Rezultati z več kot tisoč udeleženci, starimi od 18 do 91 let, so pokazali, da so merske značilnosti slovenske različice primerljive $\mathrm{z}$ značilnostmi izvirnika: ugotovili sva ustrezno notranjo skladnost treh lestvic ter ob manjših odstopanjih podprli predvideno trifaktorsko strukturo in napovedno veljavnost vprašalnika.

\section{Struktura in opisne statistike vprašalnika OTH}

Vprašalnik OTH vsebuje 18 postavk, pri čemer naj bi jih po šest merilo vsako od treh usmerjenosti $\mathrm{k}$ sreči (Peterson idr., 2005). S konfirmatorno faktorsko

\footnotetext{
${ }^{2}$ Zaradi boljšega prileganja podatkov trifaktorski strukturi brez postavk 4 in 9 , sva povezanost med usmerjenostmi $\mathrm{k}$ sreči in zadovoljstvom z življenjem preverjali tudi z izračunom rezultatov na OTH lestvici usmerjenost $\mathrm{k}$ vpletenosti brez omenjenih postavk. Rezultati korelacijskih in regresijskih analiz so bili zelo podobni za okrnjeno in izvirno lestvico in ne bi spremenili končne interpretacije podatkov.
} 
analizo sva ugotovili, da se struktura vprašalnika zgolj zadovoljivo prilega predpostavljenemu modelu, prileganje pa se je izboljšalo (čeprav še vedno ni bilo optimalno), če sva izločili postavki 4 in 9 . O takšnem vzorcu rezultatov poročajo tudi avtorji nemške različice vprašalnika (Ruch idr., 2010), visoke sekundarne nasičenosti za ti dve postavki pa so se pokazale tudi $\mathrm{z}$ izvirno različico v ZDA. Dodatne analize povezanosti med OTH lestvicami brez postavk 4 in 9 ter subjektivnim zadovoljstvom življenja so pokazale, da so odnosi med obema merama povsem primerljivi ob uporabi izvirnega oz. okrnjenega ključa za vrednotenje OTH lestvice usmerjenost k vpletenosti. Zaradi primerljivosti slovenskih rezultatov $\mathrm{z}$ rezultati tujih študij zaenkrat predlagava ohranitev izvirne, celotne lestvice. Kljub temu pa je opisane učinke potrebno upoštevati pri interpretaciji ostalih rezultatov (npr. interkorelacij).

Na splošno bi torej lahko zaključili, da so rezultati analize strukture vprašalnika podprli pričakovano strukturo, čeprav so se pokazala nekatera odstopanja. Manj kot optimalno prileganje podatkov predpostavljeni trifaktorski strukturi se je pokazalo tudi na primer pri velikem mednarodnem vzorcu (Schueller in Seligman, 2010), nemško govorečih udeležencih (Ruch idr., 2010) in tajskih študentih (Chen idr., 2009). Glede na to bi bilo utemeljeno na mednarodni ravni razmisliti o potrebi po popravljenem vprašalniku OTH (izvirniku in priredbah), ki bi vključeval le postavke, ki jasno pripadajo predpostavljenim faktorjem.

Predstavljeni rezultati kažejo na ustrezno notranjo skladnost treh lestvic OTH, dobljeni alfa koeficienti pa so po velikosti primerljivi s koeficienti, dobljenimi pri drugih vzorcih udeležencev (Peterson idr., 2005; Ruch idr., 2010; Schueller in Seligman, 2010). Ocene na treh lestvicah so se med seboj statistično pomembno povezovale. Podobno kot poročajo avtorji predhodnih študij (npr. Peterson idr., 2005; Schueller in Seligman, 2010), se je najnižja povezanost pokazala med usmerjenostjo $\mathrm{k}$ smislu in usmerjenostjo $\mathrm{k}$ užitku. Rezultati z angleško govorečimi udeleženci so pokazali zmerno visoke, a nekoliko višje korelacije med usmerjenostima $\mathrm{k}$ vpletenosti in smislu kot med usmerjenostima k vpletenosti in užitku (Peterson idr., 2005), medtem ko smo pri slovenskih udeležencih ugotovili primerljivo in zmerno visoko povezanost med usmerjenostjo $\mathrm{k}$ vpletenosti in drugima dvema lestvicama. Takšen vzorec interkorelacij se je pokazal tudi pri nemško govorečih udeležencih (Ruch idr., 2010).

Podobno kot $\mathrm{z}$ angleško in nemško različico (Peterson idr., 2005; Ruch idr., 2010), se je tudi s slovensko priredbo pokazalo, da so mlajši in neporočeni udeleženci nekoliko pogosteje poročali o doseganju sreče preko užitka kot starejši in poročeni (ali v izvenzakonski skupnosti živeči) sodelujoči. Pričujoča študija je podprla tudi ugotovitve avtorjev iz ZDA glede negativne povezanosti med izobrazbo in usmerjenostjo k užitku (tega pri nemško govorečih udeležencih niso ugotovili), poleg tega pa so imeli bolj izobraženi slovenski udeleženci nekoliko bolj izraženi usmerjenosti $\mathrm{k}$ smislu in vpletenosti $\mathrm{v}$ primerjavi $\mathrm{z}$ manj izobraženimi.

\section{Napovedna veljavnost vprašalnika OTH}

Dobljeni rezultati analize napovedne vrednosti treh usmerjenosti k sreči za zadovoljstvo z življenjem niso v celoti skladni s predhodnimi raziskavami, saj sta samo dve od treh usmerjenosti statistično pomembno prispevali $\mathrm{k}$ pojasnjeni varianci. $\mathrm{V}$ regresijski analizi sva želeli najprej upoštevati učinek demografskih značilnosti na zadovoljstvo $\mathrm{z}$ življenjem, zato sva $\mathrm{V}$ prvem koraku kot napovednike vključili spol, starost, izobrazbo in stan. Rezultati so pokazali, da izmed demografskih spremenljivk $\mathrm{k}$ napovedi zadovoljstva z življenjem statistično pomembno prispevata starost in izobrazba. Natančneje, starejši posamezniki so poročali o nekoliko nižjem zadovoljstvu z življenjem kot mlajši, bolj izobraženi posamezniki pa o nekoliko višjem kot manj izobraženi. Potrebno pa je opozoriti, da starost in izobrazba pojasnjujeta skupaj zgolj $2 \%$ variance zadovoljstva z življenjem, kar kaže na majhno velikost učinka. Rezultati niso presenetljivi, saj tudi predhodne raziskave večinoma poročajo o nizki povezanosti demografskih značilnosti z zadovoljstvom z življenjem (npr. Glaesmer, Grande, Braehler in Roth, 2011). V podobnih raziskavah napovedi zadovoljstva z življenjem na podlagi treh usmerjenosti k sreči so nekatere podobno kot najina statistično nadzorovale učinek demografskih značilnosti. V španski raziskavi (San Martín idr., 2010) niso ugotovili pomembnosti spola in starosti udeležencev pri napovedovanju zadovoljstva z življenjem. Statistično pomemben prispevek spola in starosti se je pokazal v študiji v ZDA (Vella-Brodrick idr., 2008), pri čemer sta obe spremenljivki skupaj pojasnili zgolj 0,3 \% variance zadovoljstva z življenjem, kar je praktično zanemarljivo, statistično pa pomembno zaradi velikosti vzorca $(N=18.326)$. Po drugi strani pa isti avtorji poročajo, da sta pri avstralskem vzorcu 332 oseb (28 \% moških), starih od 18 do 81 let, spol in starost pojasnila skupaj kar $20 \%$ variance zadovoljstva z življenjem. O tako velikem deležu pojasnjene variance na podlagi demografskih značilnosti pa poročajo redke raziskave. Majhen delež pojasnjene variance na podlagi demografskih značilnosti, ki smo ga ugotovili v naši raziskavi, je torej pričakovan, saj bolj kot starost, spol in podobne značilnosti na kognitivno oceno posameznikovega zadovoljstva $\mathrm{z}$ življenjem vplivajo subjektivni dejavniki, kot so npr. osebnostne značilnosti, socialne primerjave, spoprijemanje $\mathrm{s}$ kritičnimi dogodki (Diener in Ryan, 2009). 
Tri usmerjenosti k sreči kot možne subjektivne dejavnike, ki so lahko relevantni za posameznikovo oceno zadovoljstva $\mathrm{z}$ življenjem, sva vključili $\mathrm{V}$ regresijsko analizo v drugem koraku. Avtorji večine dosedanjih raziskav (Park idr., 2009; Peterson idr., 2005; Ruch idr., 2010) poročajo o pomembnosti vseh treh usmerjenosti za zadovoljstvo z življenjem, pričujoči rezultati pa kažejo kot statistično pomembna napovednika usmerjenost $\mathrm{k}$ užitku in usmerjenost $\mathrm{k}$ vpletenosti, ne pa tudi usmerjenosti $\mathrm{k}$ smislu. Ugotovljeni delež variance zadovoljstva z življenjem, ki ga pojasnjujejo tri usmerjenosti (8\%) je razmeroma nizek $\mathrm{v}$ primerjavi $\mathrm{s}$ predhodnimi raziskavami, ki kažejo, da usmerjenosti k sreči pojasnjujejo od $6 \%$ do $20 \%$ variance zadovoljstva $z$ življenjem (Peterson idr., 2005; Ruch idr., 2010; San Martín idr., 2010; VellaBrodrick idr., 2008). Možen razlog za razmeroma nizek delež pojasnjene variance bi lahko bil v uporabljeni meri zadovoljstva z življenjem. Za razliko od drugih raziskovalcev, ki so uporabili vprašalnik SWLS (Diener idr., 1985), sva zadovoljstvo z življenjem namreč ocenjevali $z$ eno samo postavko, zato je zanesljivost poročanja lahko nižja, posledično pa tudi korelacije in beta vrednosti.

Pričujoča raziskava je nepričakovano pokazala na statistično nepomemben prispevek usmerjenosti $\mathrm{k}$ smislu za zadovoljstvo $\mathrm{z}$ življenjem. Ti rezultati so $\mathrm{v}$ nasprotju z rezultati japonske raziskave, ki so pokazali statistično nepomembnost usmerjenosti k užitku za zadovoljstvo z življenjem, kar avtoji razlagajo specifikami japonske kulture (Kumano, 2011). V pričujoči raziskavi se je usmerjenost k užitku izkazala kot najpomembnejši napovednik zadovoljstva $\mathrm{Z}$ življenjem. Ali lahko torej tudi rezultate naše rezultate pripišemo kulturni specifiki? Če torej Japonci oceno zadovoljstva s svojim življenjem oblikujejo na podlagi tega, ali izbirajo smiselne dejavnosti, bi dobljeni rezultati lahko kazali, da Slovenci gradijo svojo oceno zadovoljstva $\mathrm{z}$ življenjem predvsem na oceni, ali izbirajo dejavnosti, ki jim nudijo pozitivna doživetja. Po drugi strani, pa je zadovoljstvo z življenjem konstrukt, ki se nanaša na področje hedonskega vidika blagostanja, zato se zdi smiselno, da prav usmerjenost $\mathrm{k}$ užitku največ prispeva $\mathrm{k}$ varianci ocene zadovoljstva z življenjem. Tudi Vittersø in Søholt (2011) navajata, da je zadovoljstvo z življenjem povezano predvsem $\mathrm{z}$ užitkom oziroma hedonizmom. Tako se pravzaprav zdi bolj problematično razložiti, zakaj se je v večini raziskav kot najboljši napovednik zadovoljstva $\mathrm{z}$ življenjem pokazala usmerjenost k smislu.

Usmerjenost k vpletenosti se je tako v pričujoči kot tudi $\mathrm{v}$ predhodnih raziskavah izkazala za pomemben napovednik zadovoljstva z življenjem. Čeprav Vittersø (2003) npr. meni, da zanos oz. vpletenost bolj smiselno spada k eudaimonskemu kot hedonskemu blagostanju, nekateri drugi avtorji (Waterman, 1993) menijo, da ima usmerjenost $\mathrm{k}$ vpletenosti komponente tako eudaimonskega kot hedonskega blagostanja. Vsekakor lahko rečemo, da sva $v$ pričujoči študiji ugotovili, da je za posameznike pri ocenjevanju zadovoljstva $\mathrm{Z}$ življenjem bolj pomembno, ali izbirajo svoje dejavnosti glede na to, da bodo v njih uživali ali bili v njih aktivno vključeni, ne pa izbira zaradi smiselnosti.

Poleg pomembnosti posameznih usmerjenosti $\mathrm{k}$ sreči za posameznikovo zadovoljstvo z življenjem, rezultati pričujoče raziskave kažejo na pomen tega, da posameznik srečo dosega na različne načine in ne le na enega. O najvišjem subjektivnem zadovoljstvu Z življenjem so namreč poročali tisti udeleženci, ki so poročali tudi o razmeroma visoko izraženih usmerjenostih $\mathrm{k}$ smislu, zadovoljstvu in vpletenosti. Ti rezultati podpirajo teoretično predpostavko, da je blagostanje najvišje pri posameznikih, ki živijo t. i. polno življenje, torej sledijo vsem trem potem do sreče (Peterson idr., 2005).

\section{Zaključki}

V predstavljeni študiji sva analizirali psihometrične značilnosti slovenske oblike Vprašalnika usmerjenosti k sreči, ki ga je izpolnjevalo 1064 udeležencev, starih od 18 do 91 let. Rezultati kažejo, da je prirejeni OTH zanesljiv in dokaj veljaven pripomoček za samoocenjevanje načinov doseganja sreče $\mathrm{v}$ slovenskem okolju. Seveda je imela pričujoča študija nekatere morebitne pomanjkljivosti, med katerimi velja izpostaviti zbiranje podatkov preko spleta. Kljub nekaterim pomanjkljivostim uporabe t. i. spletnega vzorca (Smyth in Pearson, 2008), spletne raziskave predstavljajo pomemben način zbiranja podatkov pri velikih in raznolikih vzorcih udeležencev ob razmeroma nizkih stroških (glej vire Peterson idr., 2005, str. 32). Primerljivost merskih značilnosti vprašalnikov, izpolnjenih $\mathrm{v}$ klasični obliki papirsvinčnik in spletni obliki, se je pokazala tudi v nemški študiji z vprašalnikom OTH (Ruch idr., 2010). Glede na to predvidevava, da uporaba spletne različice vprašalnika ni vodila do večjih izkrivljanj v rezultatih kot bi jih dobili $\mathrm{z}$ uporabo vprašalnika $\mathrm{v}$ klasični obliki. Glede na to, da po podatkih Statističnega urada Republike Slovenije (SURS, 2011) v Sloveniji svetovni splet uporablja $69 \%$ oseb starih od 10 do 74 let, meniva, da uporaba spletne različice pripomočkov ni bistveno prispevala $\mathrm{k}$ pristranosti vzorca. Po drugi strani pa je vzorec sodelujočih $\mathrm{v}$ predstavljeni študiji pristran glede starosti in spola, saj je sodelovalo bistveno več žensk kot moških ter več mlajših kot starejših oseb, kar je posledica dostopnosti udeležencev in njihove pripravljenosti na sodelovanje. 
NamenvprašalnikaOTHjezajetiinoperacionalizirati mogoče poti do sreče. Ker so avtorji (Peterson idr., 2005) poskušali združiti različne raziskovalne tradicije - hedonizem, eudaimonizem in zanos, se pojavlja vprašanje diferencialne veljavnosti treh poti. Že na teoretični ravni se namreč različni avtorji med seboj ne strinjajo, ali gre za tri ali dva različna konstrukta (Seligman, 2002; Vittersø, 2003; Waterman, 1993). $\mathrm{V}$ prihodnosti bi bila torej potrebna precej natančna teoretična analiza teh treh možnih poti do sreče, preko tega bi bilo tudi bolj jasno, kaj narediti s postavkami, ki so hkrati nasičene $\mathrm{z}$ dvema faktorjema, kar kaže na medsebojno prekrivanje različnih usmerjenosti.

Pri vprašalniku usmerjenosti k sreči OTH avtorji predlagajo tudi uporabo tipološkega pristopa (Peterson idr., 2005), saj bi na podlagi različnih kombinacij izraženosti vseh treh pristopov lahko oblikovali določene tipe oseb in predvideli določene specifike glede njihovega psihičnega blagostanja. Zaenkrat je bilo objavljenih premalo tovrstnih raziskav, ki bi kazale na obstoj enakih tipov izraženosti teh treh usmerjenosti $\mathrm{k}$ sreči pri različnih vzorcih udeležencev. $\mathrm{V}$ določenih primerih (Asendorpf, 2003; Zupančič, Podlesek in Kavčič, 2006) tipološki pristop pojasnjuje dodatno varianco poleg neodvisnih spremenljivk, zato bi bilo $\mathrm{v}$ prihodnosti smiselno preveriti doslednost predlaganih tipov v različnih kulturah oz. pri različnih skupinah udeležencev. Poleg tega bi bilo v prihodnjih študijah smiselno upoštevati tudi morebitni učinek petih velikih faktorjev osebnosti na odnos med tremi usmerjenostmi $\mathrm{k}$ sreči in merami psihičnega blagostanja. Na primer, rezultati avstralske študije (Vella-Brodrick idr., 2008) so $\mathrm{v}$ tem primeru pokazali precej manjšo dodatno napovedno vrednost usmerjenosti $\mathrm{k}$ sreči za blagostanje (od $2 \%$ do $4 \%$ pojasnjene variance), kar kaže na precejšnje prekrivanje osebnostnih značilnosti in usmerjenosti k sreči. V nadaljnjih raziskavah bi bilo torej potrebno temeljito preveriti dodatno napovedno veljavnost vprašalnika ob predhodnem upoštevanju osebnosti udeležencev. Ker je vprašalnik še razmeroma nov, je na voljo le malo podatkov o njegovi retestni zanesljivosti (npr. Ruch idr., 2010), medtem ko vzdolžnih raziskav, ki bi kazale ugotavljanje stabilnosti teh usmerjenosti v času še ni moč zaslediti v trenutno dostopni literaturi. Prav tako ostaja odprto vprašanje, kakšna je napovedna veljavnost treh načinov doseganja sreče za različne življenjske izide, kot so preživljanje časa, socialni odnosi, delovna uspešnost, itd.

\section{Literatura}

Andrews, F. M. in S. B. Withey, (1976). Social indicators of well-being. New York: Plenum Press.

Andrews, F. M. in Robinson, J. P. (1991). Measures of subjective well-being. V J. P. Robinson in P. R. Shaver (ur.), Measures of personality and social psychological attitudes (str. 61-114). San Diego, CA: Academic Press.

Anić, P. (2012). How to find happiness: Life goals and free time activities (Doctoral dissertation). Univerza v Ljubljani, Ljubljana, Slovenija.

Asendorpf, J. B. (2003). Head-to-head comparison of the predictive validity of personality types and dimensions. European Journal of Personality, 17, 327-346.

Chen, G.-H. (2010). Validating the Orientations to Happiness Scale in a Chinese sample of university students. Social Indicators Research, 99, 431-442.

Chen, L. H., Tsai, Y.-M. in Chen, M.-Y. (2009). Psychometric analysis of the orientations to happiness questionnaire in Taiwanese undergraduate students. Social Indicator Research, 98, 239-249.

Csikszentmihalyi, M. (1990). Flow, The psychology of optimal experience. New York: Harper and Row.

Cummins, R. A., Eckersley, R., Pallant, J., Van Vugt, J. in Misajon, R. (2003). Developing a national index of subjective well-being: The Australian Unity Well-being Index. Social Indicators Research, 64, 159-190.

Davern, M., Cummins, R. A. in Stokes, M. (2007). Subjective well-being as an affective/cognitive construct. Journal of Happiness Studies, 8, 429-449.

Diener, E., Emmons, R. A., Larsen, R. J. in Griffin, S. (1985). The Satisfaction with Life Scale. Journal of Personality Assessment, 49, 71-75.

Diener, E. in Ryan, K. (2009). Subjective well-being: A general overview. South African Journal of Psychology, 39, 391-406.

Field, A. (2009). Discovering statistics using SPSS (3. izd.). London: Sage Publications.

Garson, G. D. (2012). Structural equation modeling, s strani Statnotes: Topics in multivariate analysis. Pridobljeno 30.03.2012 s http:/faculty.chass.ncsu.edu/ garson/pa765/statnote.htm

Glaesmer, H., Grande, G., Braehler, E. in Roth, M. (2011). The German version of the Satisfaction with Life Scale (SWLS): Psychometric properties, validity, and population-based norms. European Journal of Psychological Assessment, 27, 127-132.

Kahneman, D. (1999). Objective happiness. V D. Kahneman, E. Diener in N. Schwarz (ur.), Well-being: The foundations of hedonic psychology (str. 3-25). New York: Russell Sage Foundation.

Kumano, M. (2011). Orientations to happiness in Japanese people: Pleasure, meaning, and engagement. Shinrigaku Kenkyu, 81, 619-624.

Lyubomirsky, S. in Lepper, H. S. (1999). A measure of subjective happiness: Preliminary reliability and construct validation. Social Indicators Research, 46, 137-155.

Mayer, J. D. (2007). Personality: A systems approach. Boston: Pearson Education.

Mellor, D., Stokes, M., Firth, L., Hayashi, Y. in Cummins, R. (2008). Need for belonging, relationship satisfac- 
tion, loneliness, and life satisfaction. Personality and Individual Differences, 45, 213-218.

Musek, J. (2000). Nova psihološka teorija vrednot. Ljubljana: Educy.

Park, N., Peterson, C. in Ruch, W. (2009). Orientations to happiness and life satisfaction in twenty-seven nations. The Journal of Positive Psychology, 4, 273-279.

Pavot, W. in Diener, E. (1993). Review of the Satisfaction with Life Scale. Psychological Assessment, 5, 164-172.

Peterson, C., Park, N. in Seligman, M. E. P. (2005). Orientations to happiness and life satisfaction: The full life versus the empty life. Journal of Happiness Studies, $6,25-41$.

Peterson, C., Ruch, W., Beermann, U., Park, N. in Seligman, M. E. P. (2007). Strengths of character, orientation to happiness, and life satisfaction. The Journal of Positive Psychology, 2, 149-156.

Ruch, W., Harzer, C., Proyer, T. R., Park, N. in Peterson, C. (2010). Ways to happiness in German-speaking countries: The adaptation of the German version of the orientations to happiness questionnaire in paperpencil and internet samples. European Journal of Psychological Assessment, 26, 227-234.

Ryan, R. M. in Deci, E. L. (2001). On happiness and human potentials: A review of research on hedonic and eudaimonic well-being. Annual Review of Psychology, 52, 141-166.

Ryff, C. D. in Singer, B. (2008). Know thyself and become what you are: A eudaimonic approach to psychological well-being. Journal of Happiness Studies, 9, 13-39.

San Martín, J., Perles, F. in Canto, J. M. (2010). Life satisfaction and perception of happiness among university students. The Spanish Journal of Psychology, 13, 617-628.

Schueller, S. M. in Seligman, M. E. P. (2010). Pursuit of pleasure, engagement, and meaning: Relationships to subjective and objective measures of well-being. The Journal of Positive Psychology, 5, 253-263.

Seligman, M. E. P. (2002.). Authentic happiness. New York: The Free Press.

Seligman, M. E. P., Parks, A. C. in Steen, T. (2005). A balanced psychology and a full life. V F. Huppert, B. Keverne in N. Baylis (ur.), The science of well-being (str. 275-283). Oxford: Oxford University Press.

Smyth, J. D. in Pearson, J. E. (2008). Internet survey methods: A review of strengths, weaknesses, and innovations. V M. Das, P. Ester in L. Kaczmirek (ur.), Social and behavioral research and the internet advances in applied methods and research strategies (str. 14-36). New York, London: Rutledge.

SURS (2011). Uporaba informacijsko - komunikacijske tehnologije vospodinjstvih in priposameznikih, Slovenija, 2011 - končni podatki. Pridobljeno 30.03.2012 s http://www.stat.si/novica_prikazi.aspx?ID=4240.
Veenhoven, R. (2012). World Database of Happiness, s strani Erasmus University Rotterdam, The Netherlands. Pridobljeno 4.4.2012 s http://worlddatabaseofhappiness.eur.nl.

Vella-Brodrick, D. A., Park, N. in Peterson, C. (2008). Three ways to be happy: Pleasure, engagement, and meaning-Findings from Australian and US samples. Social Indicators Research, 90, 165-179.

Vittersø, J. (2003). Flow versus life satisfaction: A projective use of cartoons to illustrate the difference between the evaluation approach and the intrinsic motivation approach to subjective quality of life. Journal of Happiness Studies, 4, 141-167.

Vittersø, J. in Søholt, Y. (2011). Life satisfaction goes with pleasure and personal growth goes with interest: Further arguments for separating hedonic and eudaimonic well-being. Journal of Positive Psychology, 6, 326-335.

Waterman, A.S. (1993). Two conceptions of happiness: Contrasts of personal expressiveness (eudaimonia) and hedonic enjoyment. Journal of Personality and Social Psychology, 64, 678-691.

Zupančič, M., Podlesek, A. in Kavčič, T. (2006). Personality types as derived from parental reports on 3-yearold. European Journal of Personality, 20, 285-303. 


\section{Priloga}

Tabela A. Povprečja in razpršenost ocen na treh lestvicah OTH za udeležence v različnih razvojnih obdobjih po mladostništvu

\begin{tabular}{|c|c|c|c|c|c|c|c|}
\hline & & \multicolumn{2}{|c|}{ Smisel } & \multicolumn{2}{|c|}{ Užitek } & \multicolumn{2}{|c|}{ Vključevanje } \\
\hline & & $M$ & $S D$ & $M$ & $S D$ & $M$ & $S D$ \\
\hline \multirow[t]{2}{*}{ Prehod v odraslost } & Moški $(N=77)$ & 19,29 & 4,65 & 23,61 & 3,95 & 21,05 & 3,45 \\
\hline & Ženske $(N=247)$ & 19,96 & 4,06 & 23,21 & 4,01 & 20,15 & 3,46 \\
\hline \multirow[t]{2}{*}{ Zgodnja odraslost } & Moški $(N=107)$ & 19,51 & 4,44 & 21,33 & 4,21 & 21,09 & 3,58 \\
\hline & Ženske $(N=269)$ & 20,90 & 4,35 & 22,00 & 4,33 & 21,40 & 3,44 \\
\hline \multirow[t]{2}{*}{ Srednja odraslost } & Moški $(N=73)$ & 19,38 & 5,16 & 20,81 & 5,56 & 21,15 & 4,23 \\
\hline & Ženske $(N=201)$ & 20,19 & 4,26 & 20,30 & 4,57 & 21,13 & 3,65 \\
\hline \multirow[t]{2}{*}{ Pozna odraslost } & Moški $(N=36)$ & 18,86 & 4,64 & 20,92 & 4,31 & 21,11 & 3,95 \\
\hline & Ženske $(N=54)$ & 18,44 & 5,40 & 19,39 & 5,13 & 18,81 & 3,89 \\
\hline
\end{tabular}

Opombe. Udeleženci na prehodu v odraslost so bili stari od 18 do 26 let $(M=22,2 ; S D=2,3$ leta), posamezniki v zgodnji odraslosti od 27 do 45 let $(M=35,2 ; S D=5,8$ leta), osebe v srednji odraslosti od 46 do 64 let $(M=52,6 ; S D=4,8$ leta) in osebe v pozni odraslosti 65 let ali več $(M=72,8 ; S D=6,3$ leta). 